Article

\title{
Brand Behavioral Intentions of a Theme Park in China: An Application of Brand Experience
}

\author{
JunHui Wang ${ }^{1}$, Yunseon Choe ${ }^{2,3} \mathbb{D}$ and HakJun Song ${ }^{1, *}$ \\ 1 College of Business Administration, Pai Chai University, Daejeon 35345, Korea; 528734937qq@gmail.com \\ 2 School of Community Resources and Development, Arizona State University, 411 N. Central Ave, \\ Phoenix, AZ 85004-0685, USA; Yunseon.Choe@asu.edu \\ 3 The Hainan University-Arizona State University Joint International Tourism College, Hainan University, \\ 58 Renmin Road, Haikou 570004, China \\ * Correspondence: bloodia00@hanmail.net
}

Received: 14 May 2020; Accepted: 29 May 2020; Published: 2 June 2020

check for updates

\begin{abstract}
Despite theme parks being a research hotspot, there is a paucity of research to understand the forming process of brand behavioral intentions (i.e., the intention of revisiting a theme park and the visit intentions of other theme parks under the same brand). For identifying the developing process of brand behavioral intentions from the perspective of experience, the current study developed a theoretical framework in which brand experience and memory affect visitors' satisfaction and behavioral intentions to revisit a particular theme park as well as to visit other theme parks of the same brand. The empirical results of current study showed that visitors' theme park experiences were good enough antecedents of their memories and satisfaction. It was also found that, when visitors' memory and satisfaction are high, they are likely to have stronger impact on intentions to revisit the theme park and to visit theme parks of the same brand than did memory.
\end{abstract}

Keywords: theme park; brand experience; memory; satisfaction; behavioral intentions; China

\section{Introduction}

In modern society, service providers' endeavors to find new marketing strategies have focused on customer satisfaction and loyalty because the desire that consumers want to obtain through purchasing is gradually diversifying [1]. In this era of experience economy, the core of business has changed from products to services to experiences [2]. As one of the new marketing strategies, the concept of experiential economy has received much attention. Under the experience economy, consumers expect service providers to value the consumer experience and to provide satisfactory and memorable experiences that benefit providers by encouraging consumers to repeat purchases or consumption $[1,3]$. The importance of implementing marketing strategies based on experiential economy is no exception in tourism and leisure in that experience is a major factor in differentiating tourism and leisure services to form positive images and memories from their visits.

As a representative experience product in the tourism and leisure industry, theme parks have continued to develop. The theme park is a leisure and entertainment space different from daily life. It provides tourists with different services and/or experiences to enrich their lives based on different themes. Therefore, it can be said that experience is a necessary part of the theme park industry of modern society. The definition of theme parks can be expressed as "exciting examples of capital intensive, highly developed, user-oriented, man-modified, recreational environment" [4]. It was recorded that about 252 million visited to the world's top 25 most popular theme parks in 2018, a 3.3\% increase compared to 244 million in 2017 [5]. Milman [6] and Cheng, Fang, and Chen [7] showed that theme parks have recently begun to be recognized as one of the most prevalent entertainment venues 
in the world. For theme parks, attracting visitors, stabilizing development, and ensuring profitability in a highly competitive situation are top priorities for each theme park [8]. Kim and Gupta [9] and Han et al. [10] claimed that the value of maintaining present customers is five times greater than gathering new customers. Cheng, Fang, and Chen [7] also emphasized that a theme park's brand is a determining factor for park visitors in regard to whether they will visit the park. Therefore, promoting and convincing theme park brand through the experience economy will be an effective strategy in the theme park industry, where competition is intensifying.

For theme park companies with multiple parks under the same brand, it is of importance to know whether the brand name alone can induce visits even if the content of the theme parks is different. Such a motivation would be considered a brand behavioral intention, related to the fact that, if an individual is satisfied after purchasing a product from a brand, this satisfaction may affect not only the customer's product repurchase intentions but also the customer's purchase intentions toward other products from the same brand. Therefore, inspiring theme park visitors' revisit behavioral intentions and attracting visitors to other theme parks under the same brand are important issues that theme park operators and stakeholders cannot ignore because these things are closely related to the operating company's profit growth and success. In terms of brand behavioral intention, Han and Hyun [11] stated that, the higher the consumer's satisfactory experience in a luxury hotel restaurant, the more of an intention that consumer has to make an additional purchase at that restaurant or another restaurant under the same brand.

When considering theme park visitors' brand intentions, the construct of memory should also be considered. Quan and Wang [12] stressed that the memorability of the visitor experience can have a significant impact on visitors' access to specific destinations. Visitors are likely to revisit tourist destinations with positive and unforgettable memories [13-15]. In relation to experience marketing, brand intention, and memory, Brakus, Schmitt, and Zarantonello [16] recognized brand experience as consisting of sensory (i.e., sight, smell, sound, taste, and touch stimulations evoked by the brand), affective (i.e., feelings from the brand and its emotional connection with consumers), intellectual (i.e., brand's capacity to induce consumers' concurrent and diverse thinking), and behavioral (i.e., consumers' bodily experience and interactions with the brand and lifestyles) experiences. Unfortunately, empirical research on this brand experience theory is rare, especially in the context of theme park, and previous research has not focused on the decision-making process and post-visit behaviors of theme park visitors $[7,17]$. In particular, no research has been conducted on visitors' intentions to visit other theme parks of the same brand (i.e., brand behavioral intention).

Thus, the purpose of this research is to examine visitors' experience in the theme park by applying the brand experience theory and test relationships between visitors' brand experience, memories, satisfaction, and behavioral intentions to revisit a particular theme park as well as to visit other theme parks of the same brand. With these perspectives in mind, it would be meaningful to discover the associations between the above research variables to promote sustainable brand experiences in the theme park and to explore their roles in order to clearly identify ways by which to increase visitor access and behaviors. Therefore, the results of this study can offer new strategic directions through which theme park operators can increase revisit rates, loyalty, and profits.

\section{Theoretical Framework and Research Hypothesis}

\subsection{Brand Experience}

Brand experience management seems to be important in regard to integrating sustainability for successful development and growth [18] since brand is as a significant element which determines consumers' specific choices of products or services [7]. As such, it is necessary for brand marketers to build stronger bonds with consumers by staging holistic views of brand experiences [19-21]. Although brand experience has gained attention in marketing and for understanding and managing brand loyalty, limited research has concentrated on the brand experience in the perspective of leisure and tourism [14]. 
Brand experience is composed of affective, behavioral, intellectual, and sensory variables evoked by stimuli associated with the brand (i.e., design, identity, packaging, environments, and communications of the brand) [16]. The sensory dimension focuses on brand stimuli related to one's five senses-sight, smell, sound, taste, and touch. The affective dimension of brand means one's emotional attachment to a brand. The intellectual dimension includes the capacity of a brand to involve consumers in thinking and learning about a brand. The behavioral dimension focuses on bodily experience, lifestyle, and interactions with the brand. Even though Brakus et al.'s [16] four types of experiences have been measured and conceptualized in brand management [22] and coffee house brand [23], limited study has emphasized the factor of brand experience in theme parks [18]. As such, this study attempts to examine the factors that impact consumers' loyalty and their post-purchase behaviors within the field of theme parks by concentrating on the concept of brand experience.

\subsection{Memories and Satisfaction}

Tourism experiences are critical not only in choosing the competitiveness and sustainability of tourism destinations [24] but also in leading to enhanced memories [19,25,26]. Kahneman [27] defined tourism as helping people to construct label stories about important events and to collect memories. Memories focus on strongly positive or negative events that should be remembered $[19,25]$. In the situation of the tourism industry, these memories focus on the products and services used at a destination and are associated with the tourist experience that then drives behavioral outcomes [28-30], such as intending to revisit, recommending the destination to others, and sharing post-visit experiences with friends and family [31]. Memory usually indicates the ability of ongoing processing of information when needed: memory encoding, storage, and retrieval [32]. The memory performs a critical role in understanding human behaviors since information encoded with impressive memory in the mental system organizes human activities [33-35]. Satisfaction means a positive affective reaction to a past experience [36-39]. An essential concept underpinning destination marketing research is consumer satisfaction, which is closely related to a sequential process that leads consumers to select destinations and to make decisions for consuming products and services [7,11,40-42]. A considerable amount of prior studies has examined satisfaction in tourism [36,43]. Satisfaction helps to build long-term relationships [37,44], and it has been shown to be a predictor of brand loyalty [36].

Regarding hypothesis development between brand experience, memory, and satisfaction previous research has claimed that memories are the most important characteristics of an experience [21,45-47]. It has been confirmed that meaningful memories affect consumers' decision making positively [48,49]. Previous research suggesting that the consumption experience of a product or service contributes to impressive memory formation suggests the possibility that this memory may be closely linked to the consumer's evaluation of goods [19,49]. Even though, within the context of theme park research, investigating the relationships between customer satisfaction and memories remain limited, an extensive literature has developed evidences for the influence of customer satisfaction on memory evidence [28,50-52]. Customer satisfaction can be enhanced by social interactions during the consumption experience because an individual recalling his/her memories of each other can realize satisfaction [51]. For example, research has shown that the evaluations of consumption experiences are stored in one's memory [53]. This has also been explored in studies focused on how consumers' memories influence their satisfaction and behavioral intentions [30]. For instance, Quadri-Felitti and Fiore [54] revealed a positive impact of wine tourists' memories on their satisfaction levels. This is vital because, as discussed above, customers memorize positive evaluations of products and services after having consumption experiences due to the link between memory and satisfaction [55]. This relationship was also found by Ali et al. [3] in the field of resort hotels in Malaysia. Based on the review, the following hypotheses are suggested:

Hypothesis 1 (H1). Consumers' brand experiences will affect their memories toward the theme park. 
Hypothesis 1a (H1a). Consumers' sensory experiences will affect their memories toward the theme park.

Hypothesis $\mathbf{1 b}(\mathbf{H 1 b})$. Consumers' affective experiences will affect their memories toward the theme park.

Hypothesis 1c (H1c). Consumers' intellectual experiences will affect their memories toward the theme park.

Hypothesis 1d (H1d). Consumers' behavioral experiences will affect their memories toward the theme park.

Hypothesis 2 (H2). Consumers' brand experiences will affect their satisfaction toward the theme park.

Hypothesis 2a (H2a). Consumers' sensory experiences will affect their satisfaction toward the theme park.

Hypothesis $\mathbf{2 b}(\mathbf{H} \mathbf{2 b})$. Consumers' affective experiences will affect their satisfaction toward the theme park.

Hypothesis 2c (H2c). Consumers' intellectual experiences will affect their satisfaction toward the theme park.

Hypothesis 2d (H2d). Consumers' behavioral experiences will affect their satisfaction toward the theme park.

Hypothesis 3 (H3). Consumers' memories will affect their satisfaction toward the theme park.

\subsection{Memory and Behavioral Intentions}

Behavioral intentions indicate an individual's subjective potential related to his/her desire to perform a behavior [56], resulting in his/her satisfied or dissatisfied experience. Brand loyalty is related to the level of a consumer's emotional response and attachment to a given brand [57]. Conventionally, brand loyalty has been considered a behavioral concept associated with behavioral intentions toward repeat purchasing behaviors [58]. Most research on this topic has shown that offering good memories is a better strategy to encourage customers' brand loyalty as such memories are likely to encourage consumers to select one of the products or brands related to these memories $[32,33,59,60]$. Offering positive and impressive visitors' experiences caused them to remember and consider the services affecting satisfaction and loyalty towards theme parks [61]. Thus, the relationship between brand and consumer is vital in developing brand loyalty [62]. Brand experience is fundamental in developing brand loyalty, in actively referring the brand, and in increasing a brand's profits [63]. Thus, it is recommended that a service provider needs to focus on the formation of customers' good memories [53,64]. This recommendation focuses on the consistency assumption as considered within the experience economy that the delivery of a memorable experience is a prerequisite for effective customer experience management and marketing $[46,49,65]$.

In creating memorable travel experiences, unique themes and pleasant interactions can bring customers memorable experiences in tourism and hospitality environments [31,65]. Several previous researches have revealed that customers' memories have an imperative influence on their satisfaction levels and behavioral intentions, including intentions to revisit and recommend the destinations [3,31,51,54,55,66]. For instance, Knutson et al. [67] presented that customer experience had an important influence on memory, which further formed the level of satisfaction and revisit intention. As the constructs of behavioral intentions in this study are divided into two specific concepts (i.e., behavioral intentions toward the theme park and behavioral intentions to visit the other theme parks of the same brand), the literature review provides support for the proposed relationship between memories and behavioral intentions:

Hypothesis 4 (H4). Consumers' memories will affect their behavioral intentions toward the theme park.

Hypothesis 5 (H5). Consumers' memories will affect their behavioral intentions to visit other theme parks of the same brand. 


\subsection{Satisfaction and Behavioral Intentions}

Consumer satisfaction significantly is likely to engender customer loyalty, positive social/word-of-mouth communications, and repeat purchases [68]. Prior research has revealed empirical evidence to confirm the relationships among tourist experiences, satisfaction, and revisit intentions in a wide range of the tourism and hospitality areas [11,69-74], including festivals [72,75], wine tourism [54], resort hotels [76,77], cruises [66], food experiences [78], coffee house [21], and restaurants [79]. Thus, satisfaction is seen as the antecedent of behavioral intentions on most occasions. For instance, Baker and Crompton [69] revealed the relationship among festival quality, satisfaction, and behavioral intentions to festival context. Similarly, it seems that that satisfaction significantly influenced festival participants' behavioral intentions [80]. Song, Wang, and Han [21] proved that customer satisfaction has a positive effect on the verified significant effect of customer satisfaction on their behavioral intention in a coffee house brand. Han and Hyun [81] confirmed that, when customers' satisfaction is high, they have strong intentions to revisit restaurants in a luxury hotel and to visit other restaurants of the same luxury hotel. There are several previous researches that focused on theme parks. Recent studies postulated that a high level of satisfaction results in enhanced intentions to revisit or in loyalty to the theme park [61,82-85]. As behavioral intentions in this study are composed of the two concepts mentioned previously, such as behavioral intentions toward the theme park and behavioral intentions to visit the other theme parks of the same brand in the current study, the following hypotheses are presented:

Hypothesis 6 (H6). Consumers' satisfaction will affect their behavioral intentions toward the theme park.

Hypothesis 7 (H7). Consumers' satisfaction will affect their behavioral intentions to visit other theme parks of the same brand.

\section{Method}

\subsection{Measurement}

Based on previous studies, the initial measurement items (i.e., experience consumption, memory, satisfaction, behavioral intentions, and behavioral intentions to visit other theme parks of the same brand) were created. Multiple items were used to ensure the effectiveness of the measurement of latent variables. Specifically, experience consumption was operationalized utilizing four dimensions composed of three items each taken from previous studies [14,21,65]. Memory was measured with three items adapted from previous studies $[3,30,76]$. Satisfaction was measured with three items stemming from prior studies $[1,86]$. Behavioral intentions were operationalized utilizing three items recommended by previous studies $[81,87,88]$. Behavioral intentions to visit other theme parks of the same brand were measured with three items adapted from previous value studies [81]. All of the survey questions were rated using a five-point Likert scale.

\subsection{Data Collection and Analysis}

Songcheng Theme Park (hereafter STP) is one of the popular historical and cultural theme parks located in Hangzhou, China, a city with a history of over 4700 years. The survey was conducted between February 2 and 16, 2017. This theme park in Hangzhou, with the theme of North and South Song Dynasty culture, has been in operation since May 1996. A self-managed survey questionnaire was given in person to 410 tourists who would like to participate in the survey, and a total of 364 questionnaires were returned. Among them, 49 partially and/or inconsistent questionnaires were removed, resulting in 315 questionnaires used for data analysis.

In order to ensure sufficient sample size, according to the research of Myers et al. [89], the required sample size needs to be greater than or at least equal to 5 times the number of parameters (q). The sample size used in the present study exceeds the minimum threshold, so the sample size of the present study is sufficient. At last, the present study used R-studio statistical software to analyze the characteristics 
of the respondents (descriptive analysis), and then the analysis of measurement model (confirmation factor analysis) and structural model (hypothesis testing) were carried out.

\section{Results}

\subsection{Characteristics of the Respondents}

The features of the respondents are in Table 1 . There were 315 respondents, $53.7 \%$ of them female and $46.3 \%$ male. They were mainly aged $20-29(28.6 \%)$ and $30-39(26 \%)$. In the case of jobs, $31.1 \%$ of the total were students, followed by office workers $(20 \%)$ and technicians/academics $(13.7 \%)$. In terms of educational degree background, $47.6 \%$ had a four-year university degree, while $30.8 \%$ had a two-year college degree. As for income level, $34 \%$ made 3000 yuan or less, $26.3 \%$ made between 3000 yuan and 4999 yuan, and $22.6 \%$ made between 5000 yuan and 6999 yuan. More than half of respondents $(61.6 \%)$ were married.

Table 1. Demographic Characteristics of the Respondents.

\begin{tabular}{|c|c|c|c|}
\hline Variables & Characteristic & Frequency & Percentage $(\%)$ \\
\hline \multirow{2}{*}{ Gender } & Male & 146 & 46.3 \\
\hline & Female & 169 & 53.7 \\
\hline \multirow{6}{*}{ Age } & Under 20 years old & 9 & 2.9 \\
\hline & 20-29 years old & 90 & 28.6 \\
\hline & 30-39 years old & 82 & 26.0 \\
\hline & 40-49 years old & 72 & 22.8 \\
\hline & $50-59$ years old & 37 & 11.7 \\
\hline & Over 60 years old & 25 & 7.9 \\
\hline \multirow{4}{*}{ Education level } & High school or lesser level & 23 & 7.3 \\
\hline & College level & 97 & 30.8 \\
\hline & Undergraduate level & 150 & 47.6 \\
\hline & Graduate level & 45 & 14.3 \\
\hline \multirow{9}{*}{ Occupation } & Government employee & 12 & 3.8 \\
\hline & Technician/academic & 43 & 13.7 \\
\hline & Business manager & 23 & 7.3 \\
\hline & Sales and marketing managers & 42 & 13.3 \\
\hline & Office worker & 63 & 20.0 \\
\hline & Farmer & 7 & 2.2 \\
\hline & Student & 98 & 31.1 \\
\hline & Retired & 12 & 3.8 \\
\hline & Others & 15 & 4.8 \\
\hline \multirow{3}{*}{ Marital status } & Single & 102 & 32.4 \\
\hline & Married & 194 & 61.6 \\
\hline & Others & 19 & 6.0 \\
\hline \multirow{5}{*}{ Monthly income ${ }^{a}$} & Less than 2999 & 107 & 34.0 \\
\hline & 3000 to 4999 & 83 & 26.3 \\
\hline & 5000 to 6999 & 68 & 22.6 \\
\hline & 7000 to 8999 & 33 & 10.5 \\
\hline & More than 9000 & 24 & 7.6 \\
\hline
\end{tabular}

${ }^{a}$ Unit: Yuan (Chinese currency).

\subsection{Measurement Model}

The results of the measurement model showed a satisfactory model fit to the data, $\chi^{2}(224)=522.969, p<0.001$, comparative fit index $(\mathrm{CFI})=0.942$, Tucker Lewis index $(\mathrm{TLI})=0.904$, non-normed fit index $(\mathrm{NNFI})=0.929$, and root mean square error of approximation $(\mathrm{RMSEA})=0.065$. The values of TLI and CFI equaled at least 0.9 and RMSEA was below 0.08 , which confirmed the good model fit [90]. The standardized factor loading values of the observed variables were found 
to be between 0.656 and 0.962 . (see Table 2), which were close to or surpassed the criteria of 0.7. Cronbach's alpha value is in the range of 0.76 to 0.937 , which is greater than the minimum standard of 0.7 , which means that constructs in the present study have sufficient reliability. The average variance extracted (AVE) values were also analyzed to be greater than the reference value of 0.5 [38] (see Table 3), and the value of composite reliability (CR) for multiple items were larger than the criteria of 0.7. Along with Table 2, measurement model's discriminant validity revealed to be satisfactory based on the value of AVE since all of the AVEs of each construct were greater than the squared correlation of the corresponding constructs [91]. Thus, it was regarded that the proposed measurement model fits the data well.

Table 2. Confirmatory Factor Analysis.

\begin{tabular}{|c|c|}
\hline Factors and Items & Standardized Factor Loading \\
\hline \multicolumn{2}{|l|}{ Factor 1: Sensory experiences (SEN) } \\
\hline $\begin{array}{c}\text { Songcheng Theme Park (STP) gives a strong sense of impression on my } \\
\text { sight or other senses }\end{array}$ & 0.656 \\
\hline I find STP interesting in a sensory way & 0.800 \\
\hline STP appeals to my senses & 0.771 \\
\hline \multicolumn{2}{|l|}{ Factor 2: Affective experiences (AFF) } \\
\hline STP stimulates feelings and emotion & 0.907 \\
\hline I have strong emotion for STP & 0.962 \\
\hline STP is an emotional tourism destination & 0.870 \\
\hline \multicolumn{2}{|l|}{ Factor 3: Intellectual experiences (INT) } \\
\hline STP gives me a variety of thoughts & 0.846 \\
\hline STP stimulates my curiosity to learn new things & 0.841 \\
\hline I engage in lots of thinking when I am in STP & 0.655 \\
\hline \multicolumn{2}{|l|}{ Factor 4: Behavioral experiences (BEH) } \\
\hline I am excited in STP & 0.851 \\
\hline I engage in physical activities and behaviors when I am in STP & 0.895 \\
\hline I spend lots of time staying in STP & 0.753 \\
\hline \multicolumn{2}{|l|}{ Factor 5: Memories (MEM) } \\
\hline I have remarkable memories of my visit to STP & 0.815 \\
\hline I will not forget my visit to STP & 0.845 \\
\hline I will remember many positive things about STP & 0.844 \\
\hline \multicolumn{2}{|l|}{ Factor 6: Satisfaction (SAT) } \\
\hline My visit to STP is better than I expected & 0.690 \\
\hline I am pleased with my experience at STP & 0.717 \\
\hline Overall, I am satisfied with my experiences at STP & 0.825 \\
\hline \multicolumn{2}{|l|}{ Factor 7: Behavioral intentions (BI) } \\
\hline I would visit STP again in the near future & 0.936 \\
\hline I am willing to say positive things about STP to others & 0.885 \\
\hline I am willing to recommend STP to others & 0.815 \\
\hline \multicolumn{2}{|l|}{$\begin{array}{c}\text { Factor 8: Behavioral intentions to visit other theme parks of the same } \\
\text { brand (BBI) }\end{array}$} \\
\hline I intend to visit other theme parks belonging to the same brand & 0.746 \\
\hline $\begin{array}{c}\text { I consider the STP brand to be my first choice in this tourism product } \\
\text { category }\end{array}$ & 0.660 \\
\hline $\begin{array}{l}\text { The next time I want to have a theme park experience, I will choose the } \\
\text { same brand }\end{array}$ & 0.756 \\
\hline
\end{tabular}


Table 3. Reality and Validity of the Measurement Model.

\begin{tabular}{ccccccccc}
\hline Construct & SEN & AFF & INT & BEH & MEM & SAT & BI & BBI \\
\hline \multirow{2}{*}{ SEN } & 0.555 & 0.232 & 0.481 & 0.407 & 0.368 & 0.481 & 0.516 & 0.371 \\
& & $(0.482)$ & $(0.694)$ & $(0.638)$ & $(0.606)$ & $(0.693)$ & $(0.718)$ & $(0.609)$ \\
AFF & 0.010 & 0.835 & 0.323 & 0.134 & 0.188 & 0.203 & 0.181 & 0.121 \\
& & & $(0.568)$ & $(0.367)$ & $(0.434)$ & $(0.450)$ & $(0.425)$ & $(0.349)$ \\
INT & 0.018 & 0.015 & 0.617 & 0.367 & 0.463 & 0.362 & 0.500 & 0.397 \\
& & & & $(0.606)$ & $(0.681)$ & $(0.602)$ & $(0.707)$ & $(0.630)$ \\
BEH & 0.012 & 0.012 & 0.032 & 0.697 & 0.188 & 0.190 & 0.273 & 0.210 \\
& & & & & $(0.433)$ & $(0.435)$ & $(0.522)$ & $(0.458)$ \\
MEM & 0.017 & 0.016 & 0.027 & 0.019 & 0.557 & 0.491 & 0.607 & 0.475 \\
& & & & & & $(0.700)$ & $(0.779)$ & $(0.689)$ \\
SAT & 0.012 & 0.012 & 0.019 & 0.013 & 0.021 & 0.690 & 0.651 & 0.492 \\
& & & & & & & $(0.807)$ & $(0.701)$ \\
BI & 0.018 & 0.018 & 0.029 & 0.020 & 0.030 & 0.024 & 0.775 & $0.750 *$ \\
BBI & 0.016 & 0.017 & 0.026 & 0.019 & 0.027 & 0.019 & 0.031 & 0.521 \\
$\alpha$ & 0.786 & 0.937 & 0.820 & 0.866 & 0.872 & 0.778 & 0.908 & 0.760 \\
CR & 0.788 & 0.938 & 0.827 & 0.873 & 0.873 & 0.789 & 0.911 & 0.765 \\
\hline
\end{tabular}

Notes. ${ }^{*}=$ Highest correlation between pairs of constructs; $\alpha=$ Cronbach's alpha values; $\mathrm{CR}=$ composite reliability; the values of average variance extracted (AVE) are along the diagonal; the value above the diagonal indicates the squared correlation between potential variables; the correlations among the latent constructs are in the parentheses; and the value below the diagonal refers to the standard errors among the latent constructs.

\subsection{Structural Model}

The causal relationship between latent variables in the structural model was tested because a well-fitted measurement model was established. It was also found that the level of fit of the structural model was excellent $\left(\chi^{2}=546.552, \mathrm{df}=232, p<0.001, \chi^{2} / \mathrm{df}=2.356\right.$, RMSEA $=0.066, \mathrm{CFI}=0.939$, $\mathrm{TLI}=0.900$, and NNFI $=0.928)$ (see Figure 1$)$. Sensory $\left(\beta_{\mathrm{SEN} \rightarrow \mathrm{MEM}}=0.281, p<0.001\right)$ and intellectual experiences $\left(\beta_{\text {INT } \rightarrow \text { MEM }}=0.523, p<0.001\right.$ ) had positive influences on memory. Satisfaction seems to be largely determined by sensory experience $\left(\beta_{\mathrm{SEN} \rightarrow \mathrm{SAT}}=0.463, p<0.001\right)$ and memory $\left(\beta_{\mathrm{MEM} \rightarrow \mathrm{SAT}}=\right.$ $0.368, p<0.001)$. Both memory and satisfaction had important influences on behavioral intentions $\left(\beta_{\mathrm{MEM} \rightarrow \mathrm{BI}}=0.401, \beta_{\mathrm{SAT} \rightarrow \mathrm{BI}}=0.553, p<0.001\right)$ and behavioral intentions to visit other theme parks of same brand $\left(\beta_{\mathrm{MEM} \rightarrow \mathrm{BBI}}=0.378, \beta_{\mathrm{SAT} \rightarrow \mathrm{BBI}}=0.456, p<0.001\right)$.

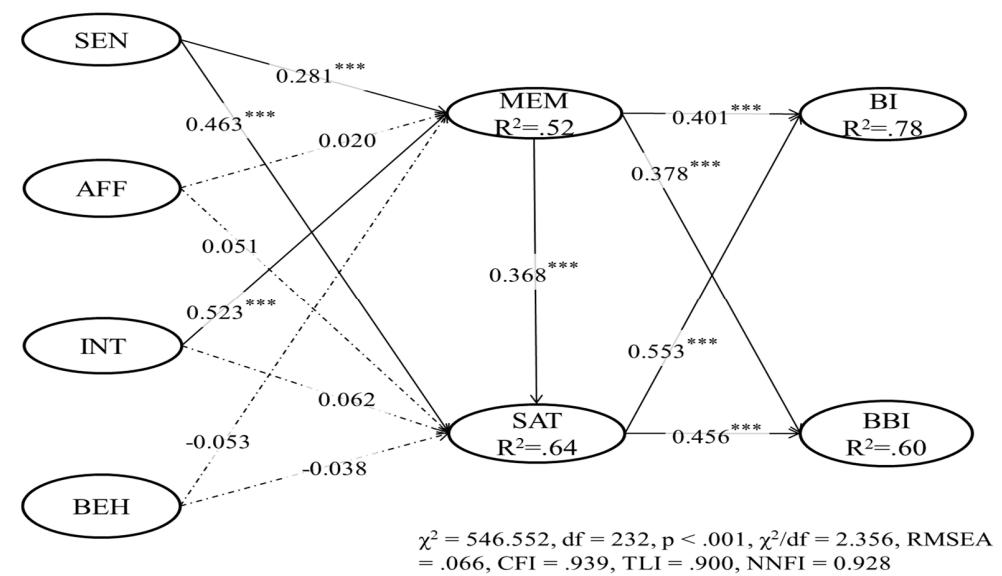

Figure 1. SEM results of the research model. $* p<0.05 ; * * p<0.01$; and ${ }^{* * *} p<0.001$. Notes: $\mathrm{SEN}=$ Sensory; AFF = Affective; INT = Intellectual; $\mathrm{BEH}=$ Behavioral; $\mathrm{MEM}=$ memory; $\mathrm{SAT}=$ Satisfaction; $\mathrm{BI}=$ Behavioral intentions to revisit the theme park; and BBI = Behavioral intentions to visit other theme parks of the same brand. 


\section{Conclusions}

Suggesting various strategies to enhance consumer satisfaction and loyalty and enticing them for repeat purchases are the core of market competition. Among the various strategies, offering memorable experiences to consumer is considered one of the most important issues in order to satisfy and retain them [19]. In this regard, this research tried to examine the formation of visitors' intentions to revisit a theme park as well as their intentions to visit other theme parks of the same brand by considering the relationships among brand experience, memory, and satisfaction. The most distinguishing feature of this study is that it is almost the very first trial to study theme park visitors' intentions-to-revisit behavior and to explore the intentions to visit other theme parks of the same brand together. From a theoretical viewpoint, this study will enhance understanding of theme park visitors' revisit intention formation. From a practical viewpoint, this study will contribute to bringing theme park managers and marketers insights for attracting more theme park visitors. It was found that behavioral intentions to a theme park (i.e., STP) and behavioral intentions to visit other theme parks of same brand were mainly explained by memory and satisfaction. Sensory and intellectual experiences had positive influences on memory, and satisfaction seems to be largely determined by sensory experience and memory. Previous researches used the four dimensions of brand experience (sensory, intellectual, affective, and behavioral) as the formative indicators of the brand experience, verified that the four dimensions also contributed differently to the overall brand experience, and then tested the influence of the overall brand experience on customer satisfaction and loyalty or brand prestige $[16,22]$. However, the present study directly confirmed the impact of sensory, intellectual, affective, and behavioral experience on memory and satisfaction, which can more clearly recognize the contribution of each dimension to memory and satisfaction. Additionally, it was found that, the higher the memory, the higher the satisfaction, the higher the intention to revisit, and the higher the intention to visit theme parks under the same brand. In other words, satisfaction was not only a precedent for revisiting intentions but also a driving factor for visiting other theme parks under the same brand, which is consistent with Han and Hyun's [81] findings mentioned above. It should be emphasized that satisfaction had a stronger impact on revisit intentions and behavior intentions to visit theme parks of the same brand than did memory because memory was also an important source of satisfaction formation. Moreover, intellectual experience had a positive indirect effect on satisfaction through memory as a mediate variable. The reason for this result may be that STP has many park activities and content related to education and intelligence, leaving a deep impression on and creating memories for tourists. These impressions and memories may be gradually transformed into satisfaction and may stimulate tourists to revisit or visit other theme parks under the same brand in order to seek a different intellectual experience.

In terms of theoretical implications, this study suggests a theoretical basis for theme park brand operators and researchers related to a new perspective on how to retain visitors. It is interesting to note that close relationships exist among the various theme parks of the same brand. Therefore, it is necessary to coordinate the overall development strategy and to play a joint role because the theme parks under the same brand are in an interactive relationship. As a specific strategy, the managers of theme parks should consider promoting or mentioning other theme parks under the same brand at the same time when promoting their theme parks via TV advertisements, posters, and leaflets. With regard to practical implications, it would be useful to make use of online short video sharing platform, such as TikTok, to attract and convey brand stories to visitors since these platforms are very popular in China. Theme park managers should also seize the opportunity to use the platforms to carry out interesting publicity on theme parks and to increase their attractiveness to previous and potential visitors. In addition, like collecting stamps, it is necessary to provide visitors with specially designed souvenirs and to encourage visitors to check into other theme parks under the same brand to get additional souvenirs. Furthermore, in order not only to increase revisit intentions but also to convince visitors to visit other theme parks under the same brand, theme parks should offer memberships and discounts. In addition, developing brand exclusive apps that can quickly push out relevant information to potential visitors should be considered. These 
apps could contain such information as ticket sales, traffic information, park introductions, maps, guides, brand stories, special performances or events, and holiday or group purchase offers. This approach could help enhance the visitor experience, could improve visitor satisfaction, and could increase visitor revisit intentions. In summary, through this research, we can achieve a deeper knowledge of the theme park visitors' behavior and bring clearer and more specific guidance and suggestions for the theme park's sustainable development from a new perspective.

\section{Limitations and Recommendations}

This study was conducted only for visitors to theme parks that have an emphasis on historical and cultural themes. Therefore, it is necessary to confirm if the results may apply to other theme parks or research environments in future research. The current research is based on the brand experience theory presented by Brakus et al. [11]. However, other concepts related to brand experience may be introduced in future studies. Due to the use of a small convenience sample of consumers, the results were limited to domestic consumers in China and may not be generalized to other settings. Therefore, further research can obtain information from a more diverse sample of consumers. As a final limitation, the data collection for the present study was conducted exclusively in the late spring festival. Since visitors to theme parks may react differently according to the season, subsequent studies need to be conducted with different data collection times.

Author Contributions: Conceptualization, H.S. and J.W.; methodology, H.S.; investigation, J.W.; writing一original draft preparation, J.W., H.S., and Y.C.; writing-review and editing, Y.C. All authors have read and agreed to the published version of the manuscript.

Funding: This research was funded by the China Scholarship Council, grant number 201808260021. The APC was funded by the authors.

Conflicts of Interest: The authors declare no conflicts of interest.

\section{References}

1. Song, H.J.; Lee, C.K.; Park, J.A.; Hwang, Y.H.; Reisinger, Y. The influence of tourist experience on perceived value and satisfaction with temple stays. The experience economy theory. J. Travel Tour. Mark. 2015, 32, 401-415. [CrossRef]

2. Mehmetoglu, M.; Engen, M. Pine and Gilmore's concept of experience economy and its dimensions: An empirical examination in tourism. J. Qual. Assur. Hosp. Tour. 2011, 12, 237-255. [CrossRef]

3. Ali, F.; Ryu, K.; Hussain, K. Influence of experiences on memories, satisfaction and behavioral intentions: A study of creative tourism. J. Travel Tour. Mark. 2016, 33, 85-100. [CrossRef]

4. Pearce, P.L.; Moscardo, G. Tourist theme parks: Research practices and possibilities. Aust. Psychol. 1985, 20, 303-312. [CrossRef]

5. Themed Entertainment Association and AECOM (2018). Available online: https://www.aecom.com/wpcontent/uploads/2019/05/Theme-Index-2018-4.pdf (accessed on 1 May 2020).

6. Milman, A. Evaluating the guest experience at theme parks: An empirical investigation of key attributes. Int. J. Tour. Res. 2009, 11, 373-387. [CrossRef]

7. Cheng, Q.; Fang, L.; Chen, H. Visitors' brand loyalty to a historical and cultural theme park: A case study of Hangzhou Songcheng, China. Curr. Issues Tour. 2016, 19, 861-868. [CrossRef]

8. Bao, J. Theme Park Research; Science Press: Beijing, China, 2015; pp. 7-35. (In Chinese)

9. Kim, H.W.; Gupta, S. A comparison of purchase decision calculus between potential and repeat customers of an online store. Decis. Support Syst. 2009, 47, 477-487. [CrossRef]

10. Han, H.; Meng, B.; Kim, W. Bike-traveling as a growing phenomenon: Role of attributes, value, satisfaction, desire, and gender in developing loyalty. Tour. Manag. 2017, 59, 91-103. [CrossRef]

11. Han, H.; Hyun, S. Role of motivations for luxury cruise traveling, satisfaction, and involvement in building traveler loyalty. Int. J. Hosp. Manag. 2018, 70, 75-84. [CrossRef]

12. Quan, S.; Wang, N. Towards a structural model of the tourist experience: An illustration from food experiences in tourism. Tour. Manag. 2004, 25, 297-305. [CrossRef] 
13. Marschall, S. 'Personal memory tourism' and a wider exploration of the tourism-memory nexus. J. Tour. Cult. Chang. 2012, 10, 321-335. [CrossRef]

14. Choe, Y.; Schuett, M.A.; Sim, K. An analysis of first-time and repeat visitors to Korean national parks from 2007 and 2013. J. Mt. Sci. 2017, 14, 2527-2539. [CrossRef]

15. Song, H.; Kim, M.; Choe, Y. Structural relationships among mega-event experiences, emotional responses, and satisfaction: Focused on the 2014 Incheon Asian Games. Curr. Issues Tour. 2018, 22, 575-581. [CrossRef]

16. Brakus, J.J.; Schmitt, B.H.; Zarantonello, L. Brand Experience: What Is It? How Is It Measured? Does It Affect Loyalty? J. Mark. 2009, 73, 52-68. [CrossRef]

17. Birenboim, A.; Anton-Clavé, S.; Russo, A.P.; Shoval, N. Temporal activity patterns of theme park visitors. Tour. Geogr. 2013, 15, 601-619. [CrossRef]

18. Wang, J.; Kim, J.; Kang, S. Antecedents and Consequences of Brand Experiences in a Historical and Cultural Theme Park. Sustainability 2019, 11, 4810. [CrossRef]

19. Pine, B.J.; Gilmore, J.H. The Experience Economy; Harvard Business Press: Brighton, MA, USA, 2011.

20. Sahin, A.; Zehir, C.; Kitapçı, H. The effects of brand experiences, trust and satisfaction on building brand loyalty: An empirical research on global brands. Procedia-Soc. Behav. Sci. 2011, 24, 1288-1301. [CrossRef]

21. Song, H.; Wang, J.; Han, H. Effect of image, satisfaction, trust, love, and respect on loyalty formation for name-brand coffee shops. Int. J. Hosp. Manag. 2019, 79, 50-59. [CrossRef]

22. Zarantonello, L.; Schmitt, B.H. Using the brand experience scale to profile consumers and predict consumer behaviour. J. Brand Manag. 2010, 17, 532-540. [CrossRef]

23. Choi, Y.G.; Ok, C.M.; Hyun, S.S. Relationships between brand experiences, personality traits, prestige, relationship quality, and loyalty: An empirical analysis of coffeehouse brands. Int. J. Contemp. Hosp. Manag. 2017, 29, 1185-1202. [CrossRef]

24. Yu, C.P.; Chang, W.C.; Ramanpong, J. Assessing Visitors' Memorable Tourism Experiences (MTEs) in Forest Recreation Destination: A Case Study in Xitou Nature Education Area. Forests 2019, 10, 636. [CrossRef]

25. Gilmore, J.H.; Pine, B.J. The Experience is the Marketing; Brown Herron Publishing: Louisville, KY, USA, 2002.

26. Gilmore, J.H.; Pine, B.J. Differentiating hospitality operations via experiences: Why selling services is not enough. Cornell Hotel Restaur. Adm. Q. 2002, 43, 87-96. [CrossRef]

27. Kahneman, D. Thinking, Fast and Slow; Macmillan: New York, NY, USA, 2011.

28. Dolcos, F.; Cabeza, R. Event-related potentials of emotional memory: Encoding pleasant, unpleasant, and neutral pictures. Cogn. Affect. Behav. Neurosci. 2002, 2, 252-263. [CrossRef] [PubMed]

29. Loureiro, S.M.C. The role of the rural tourism experience economy in place attachment and behavioral intentions. Int. J. Hosp. Manag. 2014, 40,1-9. [CrossRef]

30. Oh, H.; Fiore, A.M.; Jeoung, M. Measuring Experience Economy Concepts: Tourism Applications. J. Travel Res. 2007, 46, 119-132. [CrossRef]

31. Martin, D. Uncovering unconscious memories and myths for understanding international tourism behavior. J. Bus. Res. 2010, 63, 372-383. [CrossRef]

32. Bettman, J.R. Memory factors in consumer choice: A review. J. Mark. 1979, 43, 37-53. [CrossRef]

33. Delgadillo, Y.; Escalas, J.E. Narrative word-of-mouth communication: Exploring memory and attitude effects of consumer storytelling. Adv. Consum. Res. 2004, 31, 186-192.

34. Rubin, D.C.; Kozin, M. Vivid memories. Cognition 1984, 16, 81-95. [CrossRef]

35. Rubin, D.C.; Schrauf, R.W.; Greenberg, D.L. Belief and recollection of autobiographical memories. Mem. Cogn. 2003, 31, 887-901. [CrossRef]

36. Bennett, R.; Rundle-Thiele, S. The brand loyalty life cycle: Implications for marketers. J. Brand Manag. 2005, 12, 250-263. [CrossRef]

37. Anderson, J.C.; Narus, J.A. A model of distributor firm and manufacturer firm working partnerships. J. Mark. 1990, 54, 42-58. [CrossRef]

38. Bagozzi, R.P.; Yi, Y. On the evaluation of structural equation models. J. Acad. Mark. Sci. 1988, 16, 74-94. [CrossRef]

39. Pizam, A.; Neumann, Y.; Reichel, A. Dimensions of tourist satisfaction with a destination area. Ann. Tour. Res. 1978, 5, 314-322. [CrossRef]

40. Gallarza, M.G.; Gil Saura, I. Value dimensions, perceived value, satisfaction and loyalty: An investigation of university students' travel behaviour. Tour. Manag. 2006, 27, 437-452. [CrossRef] 
41. Chen, C.-F.; Chen, F.-S. Experience quality, perceived value, satisfaction and behavioral intentions for heritage tourists. Tour. Manag. 2010, 31, 29-35. [CrossRef]

42. Kozak, M.; Rimmington, M. Tourist Satisfaction with Mallorca, Spain, as an Off-Season Holiday Destination. J. Travel Res. 2000, 38, 260-269. [CrossRef]

43. Yüksel, A.; Yüksel, F. Shopping risk perceptions: Effects on tourists' emotions, satisfaction and expressed loyalty intentions. Tour. Manag. 2007, 28, 703-713. [CrossRef]

44. Gladstein, D.L. Groups in Context: A Model of Task Group Effectiveness. Adm. Sci. Q. 1984, $29,499$. [CrossRef]

45. Brunner-Sperdin, A.; Peters, M. What influences guests' emotions? The case of high-quality hotels. Int. J. Tour. Res. 2009, 11, 171-183. [CrossRef]

46. Pine, B.J.; Gilmore, J. Welcome to the experience economy. Harv. Bus. Rev. 1998, 76, 97-105. [PubMed]

47. Schmitt, B.H. Customer Experience Management; Wiley: Hoboken, NJ, USA, 2003.

48. Aroeira, T.; Dantas, A.C.; Gosling, M.D.S. Memorable Tourist Experience, Cognitive Perception, Reputation and Loyalty to The Destination: An Empirical Model. Tur. Visão Ação 2016, 18, 584-610. [CrossRef]

49. Kim, J.-H. Determining the Factors Affecting the Memorable Nature of Travel Experiences. J. Travel Tour. Mark. 2010, 27, 780-796. [CrossRef]

50. Curtin, S. Nature, Wild Animals and Tourism: An Experiential View. J. Ecotourism 2005, 4, 1-15. [CrossRef]

51. Fournier, S.; Mick, D.G. Rediscovering satisfaction. J. Mark. 1999, 63, 5-23. [CrossRef]

52. Brian, P.S. Tourist Experiences and Word-of-Mouth: The Mediating Effect of Memory. Ph.D. Thesis, Kansas State University, Manhattan, KS, USA, August 2016.

53. Jiang, Y.; Wang, C.L. The impact of affect on service quality and satisfaction: The moderation of service contexts. J. Serv. Mark. 2006, 20, 211-218. [CrossRef]

54. Quadri-Felitti, D.; Fiore, A.M. Destination loyalty: Effects of wine tourists' experiences, memories, and satisfaction on intentions. Tour. Hosp. Res. 2013, 13, 47-62. [CrossRef]

55. Athanassopoulos, A.; Gounaris, S.; Stathakopoulos, V. Behavioural responses to customer satisfaction: An empirical study. Eur. J. Mark. 2001, 35, 687-707. [CrossRef]

56. Fishbein, M.A.; Ajzen, I.I. Belief, Attitude, Intention and Behaviour: An Introduction to Theory and Research; Reading, Addison-Wesley: Boston, MA, USA, 2011.

57. Smith, D.C.; Aaker, D.A. Managing Brand Equity: Capitalizing on the Value of a Brand Name. J. Mark. 1992, 56, 125. [CrossRef]

58. Nam, J.; Ekinci, Y.; Whyatt, G. Brand equity, brand loyalty and consumer satisfaction. Ann. Tour. Res. 2011, 38, 1009-1030. [CrossRef]

59. Lynch, J.J.G.; Srull, T.K. Memory and Attentional Factors in Consumer Choice: Concepts and Research Methods. J. Consum. Res. 1982, 9, 18. [CrossRef]

60. Mannell, R.C.; Iso-Ahola, S.E. Psychological nature of leisure and tourism experience. Ann. Tour. Res. 1987, 14, 314-331. [CrossRef]

61. Ali, F.; Kim, W.G.; Li, J.; Jeon, H.-M. Make it delightful: Customers' experience, satisfaction and loyalty in Malaysian theme parks. J. Destin. Mark. Manag. 2018, 7, 1-11. [CrossRef]

62. Fournier, S. Consumers and Their Brands: Developing Relationship Theory in Consumer Research. J. Consum. Res. 1998, 24, 343-353. [CrossRef]

63. Morrison, S.; Crane, F.G. Building the service brand by creating and managing an emotional brand experience. J. Brand Manag. 2007, 14, 410-421. [CrossRef]

64. Levine, L.J.; Pizarro, D.A. Emotion and Memory Research: A Grumpy Overview. Soc. Cogn. 2004, 22, 530-554. [CrossRef]

65. Manthiou, A.; Kang, J.; Chiang, L.; Tang, L. (Rebecca) Investigating the Effects of Memorable Experiences: An Extended Model of Script Theory. J. Travel Tour. Mark. 2015, 33, 362-379. [CrossRef]

66. Hosany, S.; Witham, M. Dimensions of Cruisers' Experiences, Satisfaction, and Intention to Recommend. J. Travel Res. 2009, 49, 351-364. [CrossRef]

67. Knutson, B.J.; Beck, J.A.; Kim, S.; Cha, J. Service Quality as a Component of the Hospitality Experience: Proposal of a Conceptual Model and Framework for Research. J. Foodserv. Bus. Res. 2010, 13, 15-23. [CrossRef]

68. Beeho, A.J.; Prentice, R.C. Conceptualizing the experiences of heritage tourists. Tour. Manag. 1997, 18, 75-87. [CrossRef] 
69. Baker, D.A.; Crompton, J.L. Quality, satisfaction and behavioral intentions. Ann. Tour. Res. 2000, $27,785-804$. [CrossRef]

70. Han, H.; Lee, K.-S.; Chua, B.-L.; Lee, S.; Kim, W. Role of airline food quality, price reasonableness, image, satisfaction, and attachment in building re-flying intention. Int. J. Hosp. Manag. 2019, 80, 91-100. [CrossRef]

71. Lee, J.; Beeler, C. The Relationships Among Quality, Satisfaction, and Future Intention for First-time and Repeat Visitors in a Festival Setting. Event Manag. 2006, 10, 197-208. [CrossRef]

72. Liang, Y.; Illum, S.F.; Cole, S.T. Benefits received and behavioural intentions of festival visitors in relation to distance travelled and their origins. Int. J. Event Manag. Res. 2008, 4, 12-23.

73. Schmitt, B.H. Experiential Marketing. J. Mark. Manag. 1999, 15, 53-67. [CrossRef]

74. Thrane, C. Jazz Festival Visitors and Their Expenditures: Linking Spending Patterns to Musical Interest. J. Travel Res. 2002, 40, 281-286. [CrossRef]

75. Cole, S.T.; Chancellor, H.C. Examining the festival attributes that impact visitor experience, satisfaction and re-visit intention. J. Vacat. Mark. 2009, 15, 323-333. [CrossRef]

76. Ali, F.; Hussain, K.; Ragavan, N.A. Memorable Customer Experience: Examining the Effects of Customers Experience on Memories and Loyalty in Malaysian Resort Hotels. Proced.-Soc. Behav. Sci. 2014, 144, $273-279$. [CrossRef]

77. Ali, F.; Omar, R.; Amin, M. An examination of the relationships between physical environment, perceived value, image and behavioural Intentions: A SEM approach towards Malaysian resort hotels. J. Hotel Tour. Manag. 2013, 27, 9-26.

78. Chi, C.G.-Q.; Chua, B.-L.; Othman, M.; Ab Karim, S. Investigating the Structural Relationships Between Food Image, Food Satisfaction, Culinary Quality, and Behavioral Intentions: The Case of Malaysia. Int. J. Hosp. Tour. Adm. 2013, 14, 99-120. [CrossRef]

79. Ryu, K.; Lee, H.; Kim, W.G. The influence of the quality of the physical environment, food, and service on restaurant image, customer perceived value, customer satisfaction, and behavioral intentions. Int. J. Contemp. Hosp. Manag. 2012, 24, 200-223. [CrossRef]

80. Mason, M.C.; Nassivera, F. A Conceptualization of the Relationships Between Quality, Satisfaction, Behavioral Intention, and Awareness of a Festival. J. Hosp. Mark. Manag. 2013, 22, 162-182. [CrossRef]

81. Han, H.; Hyun, S.S. Impact of hotel-restaurant image and quality of physical-environment, service, and food on satisfaction and intention. Int. J. Hosp. Manag. 2017, 63, 82-92. [CrossRef]

82. Ma, J.; Scott, N.; Gao, J.; Ding, P. Delighted or Satisfied? Positive Emotional Responses Derived from Theme Park Experiences. J. Travel Tour. Mark. 2016, 34, 1-19. [CrossRef]

83. Hapsari, R. Creating educational theme park visitor loyalty: The role of experience-based satisfaction, image and value. Tour. Hosp. Manag. 2018, 24, 274-359. [CrossRef]

84. Milman, A.; Tasci, A.D.A. Exploring the experiential and sociodemographic drivers of satisfaction and loyalty in the theme park context. J. Destin. Mark. Manag. 2018, 8, 385-395. [CrossRef]

85. Wu, H.-C.; Li, M.-Y.; Li, T. A Study of Experiential Quality, Experiential Value, Experiential Satisfaction, Theme Park Image, and Revisit Intention. J. Hosp. Tour. Res. 2014, 42, 26-73. [CrossRef]

86. Cheng, Q.; Du, R.; Ma, Y. Factors influencing theme park visitor brand-switching behaviour as based on visitor perception. Curr. Issues Tour. 2014, 19, 1425-1446. [CrossRef]

87. Jung, T.H.; Ineson, E.M.; Kim, M.; Yap, M.H. Influence of festival attribute qualities on Slow Food tourists' experience, satisfaction level and revisit intention. J. Vacat. Mark. 2015, 21, 277-288. [CrossRef]

88. Sohn, H.-K.; Lee, T.J.; Yoon, Y.-S. Relationship Between Perceived Risk, Evaluation, Satisfaction, And Behavioral Intention: A Case of Local-Festival Visitors. J. Travel Tour. Mark. 2016, 33, 1-18. [CrossRef]

89. Myers, N. Sample Size and Power Estimates for a Confirmatory Factor Analytic Model in Exercise and Sport: A Monte Carlo Approach. Res. Q. Exerc. Sport 2011, 82, 412-423. [CrossRef] [PubMed]

90. Hair, J.F.; Ringle, C.M.; Sarstedt, M. PLS-SEM: Indeed a Silver Bullet. J. Mark. Theory Pract. 2011, 19, $139-152$. [CrossRef]

91. Fornell, C.; Larcker, D.F. Evaluating structural equation models with unobservable variables and measurement error. J. Mark. Res. 1981, 18, 39-50. [CrossRef]

(C) 2020 by the authors. Licensee MDPI, Basel, Switzerland. This article is an open access article distributed under the terms and conditions of the Creative Commons Attribution (CC BY) license (http://creativecommons.org/licenses/by/4.0/). 